\section{Genetic variation and gain in progenies of crambe}

\section{Ana Carolina da Costa Lara-Fioreze ${ }^{1^{*}}$, Laerte Gustavo Pivetta ${ }^{2}$, Maurício Dutra Zanotto ${ }^{3}$ and Cristiane Harumi Okita ${ }^{4}$}

\begin{abstract}
The objective of this study was to estimate the genetic variability of a Brazilian cultivar of crambe, as well as to estimate the genetic gain, with selection focusing on grain yield in crambe. Eighty two progenies were selected within the FMS Brilhante cultivar in 2009. The progenies were evaluated in 2010 and 2011 in Botucatu and São Manuel, Sao Paulo State, with the FMS Brilhante used as control. Great genetic variability was verified in all of the characteristics studied. Significant interactions of progenies $x$ location and progenies $x$ year were observed based on the joint analysis. The genetic gain for the grain yield ranged from 9.3 to $48.9 \%$ on the individual analysis and ranged from 6.6 to $21.4 \%$ on the joint analysis. The selection used in the base plant population of FMS Brilhante was efficient to increase grain yield in crambe.
\end{abstract}

Key words: Genetic variability, genetic gain with selection, individual analysis, joint analysis.

\section{INTRODUCTION}

The demand and the development of new crops resulting in raw materials to supply the energy industry are growing throughout the world. Studies on oilseed plants have been conducted in search of oil with suitable characteristics for biofuel production. In addition to the energy role, the oil is applied to a wide range of uses in the chemical industry. Among the oilseed species, special attention has been given to the species Crambe abyssinica Hochst in recent decades.

Crambe seed is the main raw material of the crop with about $34 \%$ oil containing 55-60\% erucic acid (Lessman and Berry 1967). Due to its high erucic acid content, the oil has a promising range of applications in the oleochemical industry. Crambe oil has high viscosity and high smoke point, which makes this crop particularly suitable for certain industrial uses (Lazzeri et al. 1997). One example is the process of chemical synthesis such as erucamide (in addition to some types of plastic films), brassylic acid (for nylon and polymer manufacturing industries), and sulfur derivatives (used as additives for rubbers) (Hinman 1986).

In Brazil, crambe has attracted the interest of farmers, since it is a choice for winter growth, being an excellent alternative for off-season crop sown after soybean growth (Falasca et al. 2010). Crambe is an interesting option for crop rotation with soybean, corn, wheat and other grains grown in the Southeast, South, and Center-West regions of Brazil. Additionally, this crop has advantages such as short cycle and relative drought tolerance (Andrade et al. 2006). It is
Crop Breeding and Applied Biotechnology 16: 132-140, 2016 Brazilian Society of Plant Breeding. Printed in Brazil http://dx.doi.org/10.1590/1984$70332016 v 16$ n2a20
*Corresponding author: E-mail: ana.lara@ufsc.br

Received: 30 July 2014 Accepted: 12 November 2015

${ }^{1}$ Universidade Federal de Santa Catarina, Rodovia Ulysses Gaboardi, km 03, 89.520-000, Curitibanos, Santa Catarina, Brazil

${ }^{2}$ Instituto Federal de Educação, Ciência e Tecnologia (IFMT), 78.043-400, Sorriso, Mato Grosso, Brazil

${ }^{3}$ Universidade Estadual Paulista (UNESP), Faculdade de Ciências Agronômicas, 18.610-307, Botucatu, São Paulo, Brazil ${ }^{4}$ Universidade Federal de Santa Catarina, 88.010-970, Florianópolis, Santa Catarina, Brazil 
also a crop with low cost of production once the growth is fully mechanized using existing machinery for other crops (Pitol 2008, Pitol et al. 2010).

The introduction of crambe in Brazil was in the ' 90 s by researchers from the Fundação Mato Grosso do Sul - Maracajú, and after years of research, the first and only cultivar registered in Brazil was the cultivar 'FMS Brilhante'. Under Brazilian conditions, the FMS Brilhante has grain yield from 1000 to $1500 \mathrm{~kg} \mathrm{ha}^{-1}$ (Pitol et al. 2010, Pitol 2008), which is considered below the productive potential for the species Crambe abysinica Hochst. In Brazil, there are no reports of breeding programs being conducted with crambe, except for the cultivar FMS Brilhante.

Crambe presents flowers hermaphrodites and is preferentially autogamous plant, with intercrossing rates ranging from 9 to $14 \%$ (Vollmann and Ruckenbauer 1993), it is known that the cross-fertilization can vary considerably regarding genetic material and growth environment. The breeding program at the University of North Dakota developed several crambe genotypes with superior performance. Undoubtedly, this is the most consistent breeding program of crambe, and it has been performed through the evaluation of existing germplasm by selection among and within populations developed through hybridization and subsequent selfing. The method used in crambe to obtain pure lines is a combination of the population method (bulk) and the genealogical method (pedigree). The objectives of the crambe breeding program are to increase grain yield, grain oil content, and erucic acid in the oil as well as to reduce glucosinolate content (antinutritional factors) and promote tolerance to diseases caused by Alternaria and Sclerotinia (Knights 2002). However, the breeding programs efficiency has been hampered by the lack of genetic variability (Mastebroek et al. 1994, Lessman and Meier 1972, Papathanasiou et al. 1966).

Considering the relevant importance that crambe has acquired in Brazil, as well as the absence of genetic material more productive and adapted to Brazilian conditions, the species Crambe abyssinica Hochst was inserted in an existing non-food oilseed crops breeding program at Faculdade de Ciências Agronômicas, da Universidade Estadual Paulista (UNESP), Botucatu (SP), Brazil. The objective of this study was to estimate the genetic variability in a Brazilian cultivar of crambe (FMS Brilhante) as well as to estimate the genetic gain with selection for grain yield.

\section{MATERIAL AND METHODS}

Experiments were conducted in two experimental farms of the College of Agricultural Sciences, UNESP, in Botucatu

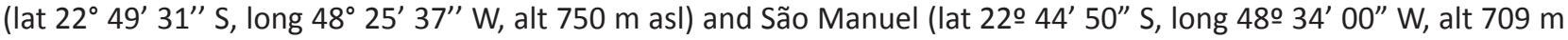
asl), São Paulo State, Brazil, during three consecutive years (2009, 2010, and 2011) under off-season conditions. The experimental area soil was a Dystric Red Nitosol (Alfisol) in Botucatu and a Red Yellow Latosol (Oxisol) in São Manuel (FAO 1974).

The cultivar FMS Brilhante was sown in two locations in March 2009, and it was used as base population for this research. Then 150 plants from each location (Botucatu and São Manuel) were selected and harvested individually. Out of the 300 progenies, 82 were used for evaluation. The progenies were evaluated in off-season on the years of 2010 and 2011 in Botucatu and São Manuel, along with the cultivar FMS Brilhante as control. The experimental design was a randomized bock design with three replications. The plots consisted of four rows with $1 \mathrm{~m}$ spaced $0.25 \mathrm{~m}$, with 10 plants per row. The harvest rows used for the evaluation were only the central ones. In April 2010 and 2011, 20 seeds per row were sown manually. Afterwards the plants were thinned with 10 plants remaining per row. Fertilization was based on the soil analysis, using 04-14-08 formulated fertilizer. Irrigation and phytosanitary control were not used.

The following characteristic analysis were a) thousand grain weight: determined by weighing eight replicates of 100 seeds each batch, using an analytical balance with milligram precision scale, and multiplying the average of the results for 10; b) number of branches per plant: number of branches of each plant per plot were counted at harvest; $c$ ) grain yield in $\mathrm{kg} \mathrm{ha}^{-1}$ : estimated as function of the yield of each plot (harvest rows) corrected for $13 \%$ moisture content; and d) oil content in \%: determined by nuclear magnetic resonance method, through the calibration curve of crambe oil, using samples of approximately $7.0 \mathrm{~g}$ of seeds per plot, at EMBRAPA Instrumentação Agropecuária, São Carlos, SP, Brazil.

Individual analysis of variance for each experiment and joint analysis of variance between years and between locations were performed for the characteristics evaluated according to $F$ test $(p<0.05)$, and the means were compared by Scott Knott test $(p<0.05)$. Genetic variance among progenies, environmental variance, and variance of the interaction progeny 


\section{ACC Lara-Fioreze et al.}

$x$ environment were estimated based on the mathematical expectation of mean squares. The parameters below were estimated for each characteristic, using the following expressions:

Mean environmental variance: $\sigma_{\mathrm{e}}^{2}=\frac{\mathrm{MSe}}{\mathrm{r}}$

Mean genotypic variance: $\sigma_{\mathrm{g}}^{2}=\frac{\mathrm{MSg}-\mathrm{MSe}}{\mathrm{r}}$

Where:

MSg: is the mean square of progenies for the individual analysis;

MSe: is the mean square error of the individual analysis;

$r$ : is the number of replications.

Estimates of genetic variance, variance of the interaction progeny $x$ environment and environmental variance for the joint analysis between years and between locations were obtained using the following expressions:

Genetic variance: $\sigma_{\mathrm{g}}^{2}=\frac{\mathrm{MSg}-\mathrm{MSe}}{\mathrm{re}}$

Variance of the interaction progeny $x$ environment: $\sigma_{\mathrm{ge}}^{2}=\frac{\text { MSge-MSe }}{\mathrm{r}}$

Environmental variance: $\sigma_{\mathrm{e}}^{2}=\mathrm{MSe}$

Where:

MSg: is the mean square of progenies for the joint analysis between years or between locations;

MSge: is the mean square of progenies $\mathrm{x}$ years or progenies $\mathrm{x}$ locations;

MSe: is the mean square error of the joint analysis between years or locations.

$r$ : is the number of replications;

e: is the number of environments.

For the individual analysis, the heritability coefficient was obtained according to the formula: $h_{\mathrm{b}}^{2}=(M S g-M S e) / M S g$

Confidence intervals of the heritability coefficients between progeny from the individual analysis were estimated according Knapp et al. (1985):

Intervals of the heritability coefficients: $\mathrm{P}\left\{1-\left[\frac{\mathrm{M}_{1}}{\mathrm{M}_{2}} \mathrm{~F}_{1-\frac{\alpha}{2}, \mathrm{df} 2 ; \mathrm{df1}}\right]^{-1} \leq \mathrm{h}_{\mathrm{b}}^{2} \leq 1-\left[\frac{\mathrm{M}_{1}}{\mathrm{M}_{2}} \mathrm{~F}_{\frac{\alpha}{2}}, \mathrm{df} 2 ; \mathrm{df1}\right]^{-1}\right\}$

Where:

$M_{1}=M S g ; M_{2}=M S e ; d f 1$ = degrees of freedom for progenies; df2 = degrees of freedom for error;

The expected genetic gain with selection based on the individual analysis for the grain yield $\left(\mathrm{kg} \mathrm{ha}^{-1}\right)$ with $10 \%$

intensity of selection was calculated by the equation: $\mathrm{Gs}=\mathrm{i} \frac{\sigma_{g}^{2}}{\sqrt{\sigma_{g}^{2}+\frac{\sigma_{g}^{2}}{r}}}$
$\quad$ Where:

$\mathrm{i}=1.755$ = standardized selection differential corresponding to an intensity of selection $10 \%$ (Vencovsky 1978).

The expected genetic gain based on the average of progenies was transformed into percentage by the formula: $G s(\%)=\frac{G s}{M p} 100$.

Where: $\mathrm{Mp}=$ overall mean of progenies

The heritability coefficients in average of progenies level for the joint analysis between locations or between years were obtained by the expressions: $h_{\mathrm{b}}^{2}=(\mathrm{MSg}-\mathrm{MSe}) / \mathrm{MSg}$ 
Confidence intervals of the heritability coefficients between progeny from the joint analysis were estimated according Knapp (1985):

Intervals of the heritability coefficients: $\mathrm{P}\left\{1-\left[\frac{\mathrm{M}_{2}}{\mathrm{M}_{3}} \mathrm{~F}_{1-\frac{\alpha}{2}, \mathrm{df} 3 ; \mathrm{df} 2}\right]^{-1} \leq \mathrm{h}_{\mathrm{b}}^{2} \leq 1-\left[\frac{\mathrm{M}_{2}}{\mathrm{M}_{3}} \mathrm{~F}_{\frac{\alpha}{2}}, \mathrm{df3} ; \mathrm{df} 2\right]^{-1}\right\}$

Where:

$M_{2}=M S g ; M_{3}=M S e ; d f 3$ = degrees of freedom for error; df2 = degrees of freedom for progenies.

The expected genetic gain with selection based on the joint analysis in $\mathrm{kg} \mathrm{ha}^{-1}$ with intensity of selection $10 \%$ were obtained by the expression: $\mathrm{Gs}=\mathrm{i} \frac{\sigma_{g}^{2}}{\sqrt{\frac{M S g}{r g}}}$. The transformation of the expected genetic gain in percentage of the progeny average was obtained by the formula: $G s(\%)=\frac{G s}{M p} 100$.

Where: $\mathrm{Mp}=$ overall mean of progenies in the joint analysis.

Statistical analysis was performed using the computer software Genes (Cruz 2001).

\section{RESULTS AND DISCUSSION}

The basic premise for using the method of individual selection with progeny test is the existence of genetic variability in the initial population, without crosses or induced mutation to enlarge it. The choice of cultivar FMS Brilhante as base population was based on the observed variability for various features, mainly related to plant architecture. This variability could be proven by the existence of significant differences $(p<0.05)$ between progenies in all experiments for almost all characteristics, except for grain yield in São Manuel (2010) and number of branches in Botucatu (2011) (Table 1). Furthermore, the estimated genetic variance reaffirms the variability among the progenies, which were all different from zero (Table 3).

The range of variation was large for all the features, especially grain yield (Table 2). The progenies were grouped by the Scott Knott test $(p<0.05)$ ranging from two to four groups. The mean values observed for the characteristics evaluated are in accordance to the values reported for crambe (Table 2). The University of North Dakota, which has the most consistent breeding program of crambe, carries out evaluations in all crop seasons comparing the cultivars of the breeding program and newly selected lines. In 2011, NDSC Carrington Research Extension Center published the results for grain yield in the cultivars BelAnn, Meyer, and Westhope, ranging from 1501.8 to $1637.5 \mathrm{~kg} \mathrm{ha}^{-1}$. These results pointed to higher grain yield, showing that the selected progenies have potential for improving the crambe growth in Brazil. The average grain yield of crambe progenies was higher than the average grain yield of canola, an oilseed crop also from Brassica family with grain yield reaching 1300 to $1700 \mathrm{~kg} \mathrm{ha}^{-1}$, according to studies by Kruger at al. (2011) and Kaefer et al. (2014). Regarding the grain oil content, which is a relevant characteristic in crambe, Lessman (1975) observed values from 27.1 to $33.3 \%$ in lines of crambe evaluated in two years, being similar to the values obtained in this study.

Another important aspect highlighted is the fact that for some characteristics, the average of 82 progenies was higher than the average of the control (FMS Brilhante) (Table 2). For grain yield the maximum value presented by the progenies was higher than the control mean in 43.3, 51.8, 43.2 and 48.4\%, respectively in Botucatu (2010), São Manuel (2010), Botucatu (2011) and São Manuel (2011). These values could have been higher if the number of progenies were larger. However, the 300 progeny could not be used due to the small amount of seed obtained from each plant, which was insufficient to conduct all experiments. There is no correct number of plants to select in the method of individual selection with progeny test, although the chances of finding superior genotypes increase with greater number of selected plants. Lessman (1975) used the method of individual selection with progeny test in C. abyssinica and selected 162 lines. The author evaluated the genetic variability based on the characteristics of plant height, oil content, test weight, yield, days to bloom and glucosinolate content, and found significant differences, except for the glucosinolate content. Using the same method, Ramalho et al. (1982) and Santos et al. (2002) found genetic variability with 500 families and in the following steps, with 289 and 98 families.

As shown on Table 1, all characteristics demonstrated significant differences on the effect of progenies in all joint 
analysis performed for locations and years. In the joint analysis of location, the effect of locations was not significant only for the number of branches in 2011, indicating that the mean of the progenies did not differ from one location to another. Regarding the effect of the interaction progenies $x$ locations, significant differences for all characteristics were found indicating that the progenies showed different responses, in the two locations, for the characteristics evaluated. Effect of years was also observed, with significant differences in the mean of the progenies for all characteristics. As in the interaction progenies $x$ location, the effect of interaction progenies $x$ years was significant for all characteristics. Fontana et al. (1998) studied the variability for the grain yield among American cultivars and the cultivar 'Mario', obtained in Italy, and no significance for the interaction genotype $x$ year was found. The significance of the interactions progenies $x$ locations and progenies $x$ years might be considered when there is interest in selecting superior progenies. A genetic material requires the presence of superiority in relation to the characteristic of interest as well as to be stable at the growth environmental conditions. Thus, the significance of the interaction between progenies and locations indicates that these progenies showed different expression of the characteristic related to locations and years. Furthemore, the genotype $x$ environment interaction is important for plant breeding because it affects the genetic gain and recommendation and selection of cultivars with wide adaptability (Souza et al. 2009, Deitos et al. 2006).

Table 1. Mean squares of the individual and joint analyses of the experiments of crambe progenies

\begin{tabular}{|c|c|c|c|c|}
\hline Source of variation & Thousand grain yield (g) & Number of branches & $\begin{array}{c}\text { Grain yield } \\
\left(\mathrm{kg} \mathrm{ha}^{-1}\right)\end{array}$ & $\begin{array}{l}\text { Oil content } \\
\text { (\%) }\end{array}$ \\
\hline & \multicolumn{4}{|c|}{ Botucatu (SP) 2010} \\
\hline Progenies & $1.42 *$ & 17.93* & $582173^{*}$ & $12.32 *$ \\
\hline \multirow[t]{2}{*}{ Error } & 0.50 & 6.55 & 323815 & 4.77 \\
\hline & \multicolumn{4}{|c|}{ Botucatu (SP) 2011} \\
\hline Progenies & $0.93^{*}$ & 6.15 & 268539* & $12.11 *$ \\
\hline \multirow[t]{2}{*}{ Error } & 0.57 & 4.50 & 93412 & 7.02 \\
\hline & \multicolumn{4}{|c|}{ São Manuel (SP) 2010} \\
\hline Progenies & $1.15^{*}$ & $7.32 *$ & 439155 & $5.70^{*}$ \\
\hline \multirow[t]{2}{*}{ Error } & 0.65 & 4.59 & 368050 & 2.39 \\
\hline & \multicolumn{4}{|c|}{ São Manuel (SP) 2011} \\
\hline Progenies & $1.77^{*}$ & $20.66^{*}$ & $142612^{*}$ & $12.70^{*}$ \\
\hline \multirow[t]{2}{*}{ Error } & 0.39 & 4.77 & 65318 & 2.68 \\
\hline & \multicolumn{4}{|c|}{ Botucatu and São Manuel (2010) } \\
\hline Progenies & $1.81^{*}$ & $17.35^{*}$ & $496545^{*}$ & $12.10 *$ \\
\hline Locations & $84.07 *$ & $37.14^{*}$ & $5210589 *$ & $1047.39 *$ \\
\hline Prog X Loc. & $0.76^{*}$ & $7.95^{*}$ & $524784^{*}$ & $5.92 *$ \\
\hline \multirow[t]{2}{*}{ Error } & 0.57 & 5.55 & 344522 & 3.74 \\
\hline & \multicolumn{4}{|c|}{ Botucatu and São Manuel (2011) } \\
\hline Progenies & $1.57^{*}$ & $12.17^{*}$ & $178408^{*}$ & $17.03^{*}$ \\
\hline Locations & $77.65^{*}$ & 1.69 & $38071561^{*}$ & $374.87^{*}$ \\
\hline Prog. X Loc. & $1.13^{*}$ & $14.63^{*}$ & $232743^{*}$ & $7.78^{*}$ \\
\hline \multirow[t]{2}{*}{ Error } & 0.56 & 4.84 & 79359 & 4.85 \\
\hline & \multicolumn{4}{|c|}{ Botucatu (2010-2011) } \\
\hline Progenies & $1.47^{*}$ & $14.96^{*}$ & $441427^{*}$ & $15.53^{*}$ \\
\hline Years & $247.31^{*}$ & $4489.32 *$ & $98583841^{*}$ & $1586.24 *$ \\
\hline Progenies X Years & $0.88^{*}$ & $9.36^{*}$ & $407445^{*}$ & $8.95^{*}$ \\
\hline \multirow[t]{2}{*}{ Error } & 0.58 & 5.71 & 208584 & 6.07 \\
\hline & \multicolumn{4}{|c|}{ São Manuel (2010-2011) } \\
\hline Progenies & $1.85^{*}$ & $15.70^{*}$ & $274773^{*}$ & $10.93 *$ \\
\hline Years & $4.69 *$ & $3931.65^{*}$ & 193171387* & $717.53^{*}$ \\
\hline Progenies $\mathrm{X}$ Years & $1.09 *$ & $12.25^{*}$ & $306401^{*}$ & $7.42^{*}$ \\
\hline Error & 0.52 & 4.66 & 214730 & 2.65 \\
\hline
\end{tabular}

$* p<0.05$. 
In general, the experimental coefficients of variation reflect the good experimental precision, due to the nature of this study, with a large number of treatments, except for grain yield evaluated on the experiment in São Manuel in 2011 (50,13\%) (Table 3), considered high, according Pimentel Gomes (1985). In this evaluation, there was a problem

Table 2. Summary of descriptive analysis and groups formed by the Scott Knott test for the characteristics evaluated in progenies of crambe

\begin{tabular}{|c|c|c|c|c|}
\hline Characteristics & $\begin{array}{c}\text { Mean } \\
\text { Progenies }\end{array}$ & $\begin{array}{l}\text { Mean } \\
\text { cultivar }\end{array}$ & $\begin{array}{l}\text { Range of } \\
\text { variation }\end{array}$ & $\begin{array}{l}\text { Scott-Knott } \\
\text { groups }\end{array}$ \\
\hline Thousand grain weight & 6.30 & 6.60 & $4.51-7.79$ & 2 \\
\hline Grain yield & 1958.30 & 1611.30 & $536.60-2843.60$ & 2 \\
\hline Oil content & 28.84 & 29.70 & $23.00-33.33$ & 2 \\
\hline Number of branches & 14.35 & 14.30 & $11.00-18.33$ & 2 \\
\hline Grain yield & 1753.00 & 1381.70 & 880.20 - 2869.60 & - \\
\hline \multirow[t]{2}{*}{ Oil content } & 31.73 & 30.61 & $27.77-34.36$ & 2 \\
\hline & \multicolumn{4}{|c|}{ Botucatu (SP) 2011} \\
\hline Thousand grain weight & 7.72 & 7.72 & $6.11-8.97$ & 2 \\
\hline Oil content & \multicolumn{4}{|c|}{ São Manuel (SP) 2011} \\
\hline Thousand grain weight & 6.93 & 6.61 & $4.79-8.68$ & 3 \\
\hline Number of branches & 8.75 & 10.66 & $3.33-15.33$ & 2 \\
\hline Grain yield & 509.87 & 563.40 & $20.50-1092.2$ & 2 \\
\hline Oil content & 34.14 & 34.27 & $25.34-39.24$ & 4 \\
\hline
\end{tabular}

Table 3. Estimation of genetic parameters in Crambe progenies from the individual analysis

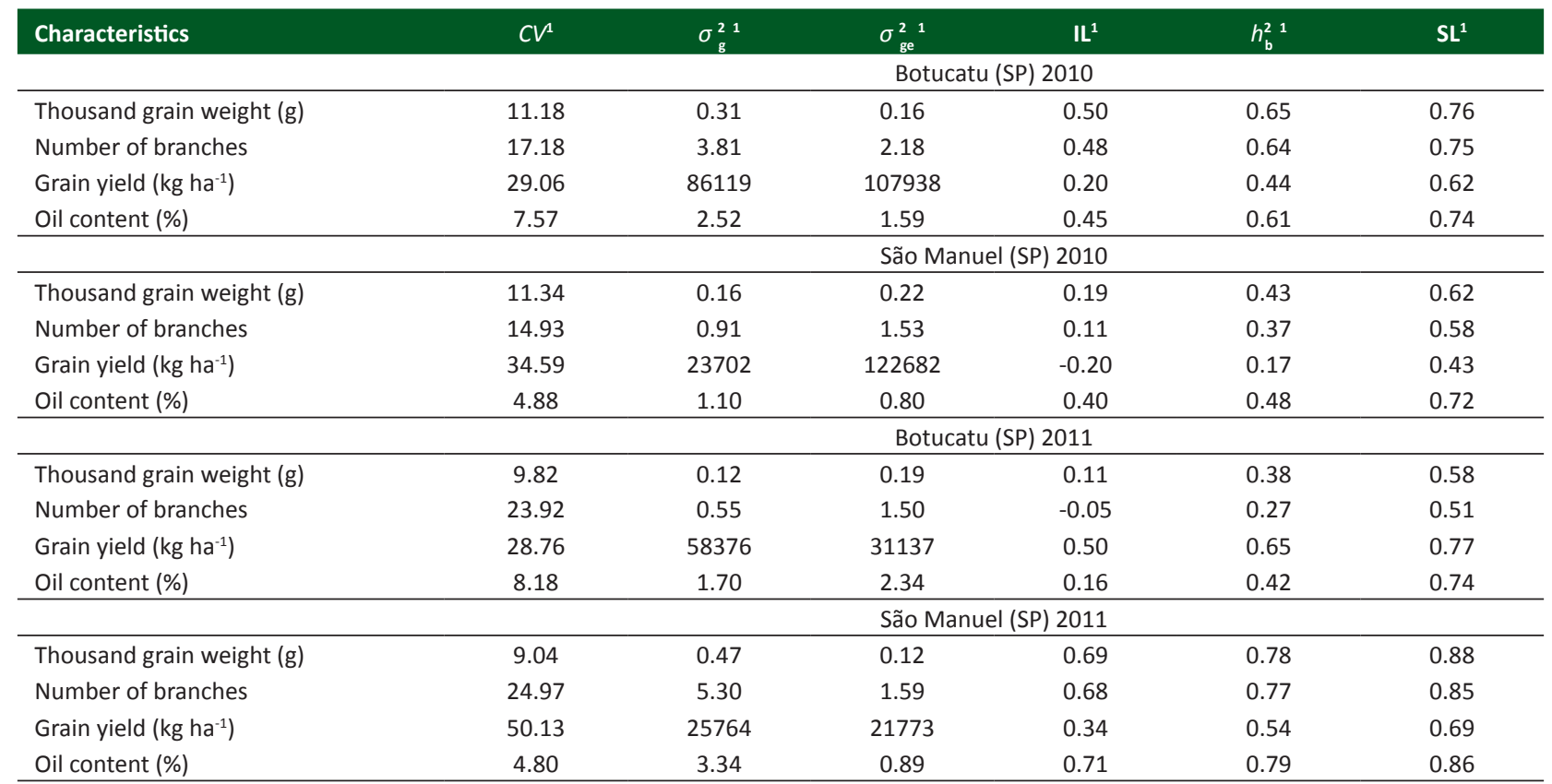

${ }^{1} \mathrm{CV}$ : experimental coefficient of variation; $\sigma_{\mathrm{g}}^{2}$ : genetic variance among progenies; $\sigma_{\mathrm{ge}}^{2}$ environmental variance (error); IL: inferior limit heritability; $h_{\mathrm{b}}^{2}$ : broad-sense heritability; SL: superior limit heritability. 
with ants attack in the field. The heritability coefficients reinforce the presence of genetic variability, which ranged from 0.17 to 0.79 , whereas the lowest values were observed at grain yield $(0.17)$ and number of branches $(0.27)$ (Table 3$)$, due to the fact that are characteristics strongly influenced by the environment. In addition, the inferior limits of the confidence intervals for these same characteristics were negative. Negative heritability was also found by other authors in soybean (Mauro et al. 1999, Azevedo Filho et al. 1998) and bean (Coelho et al. 2002) crop. Many authors prefer to consider negative heritability equal to zero, to avoid embarrassment in the discussion of your data, making it possible the occurrence of negative heritability when the variance is low (Lynch and Walsh 1998) or when the magnitude of the environmental variance is very high.

Lessman (1975) found heritability coefficients of 24,45 , and $88 \%$, respectively, for the grain oil content, grain weight, and grain yield in crambe lines obtained by the same selection method used in this research. On a research conducted by Vollmann and Ruckenbauer (1993), the heritability coefficients ranged 19-69\%. It was observed that the estimates of variance of the interaction progenies $x$ locations or progenies $x$ years were always greater than the variance of progenies for the grain yield (Table 4), which was also verified in wheat (Cargnin et al. 2006) and common bean (Coimbra et al. 1999) for the grain yield characteristic, demonstrating, once again, the strong environmental influence on the characteristic The magnitude and type of the interaction progenies $x$ locations and progenies $x$ years may hamper the selection of progeny with stable response in different environments. However, on thousand grain weight, number of branches, and oil content, with a few exceptions, the estimate of variance of progenies was greater than the variance of the interaction (Table 4). The magnitude of the estimated genetic variance in joint analysis is more accurate than the individual analysis because the variance of genotype $x$ environment interaction can be calculated, and is not inflating the variance. The heritability coefficients ranged from 0.22 to 0.76 , whereas the lowest values $(0.22$ and 0.26$)$ were observed at grain yield, besides presenting negative inferior limits. On a research conducted by Vollmann and Ruckenbauer (1993), for the joint analysis of the data, the heritability was lower than $5 \%$. Low values of heritabilities were found by Meier and Lessmann (1973) on grain yield and oil content in progenies from crossing in crambe.

In this study, the objective was to select superior progenies of crambe from a population of the cultivar FMS Brilhante, based on grain yield. The selection based on the analysis of each individual experiment resulted in genetic gain ranging from 9.3 to $48.9 \%$, with consequent increases in the grain yield from 163.1 to $432.8 \mathrm{~kg} \mathrm{ha}^{-1}$, which is quite acceptable

Table 4. Estimation of genetic parameters in Crambe progenies from the joint analysis

\begin{tabular}{|c|c|c|c|c|c|c|c|}
\hline Characteristics & $\mathrm{CV}^{2}$ & $\sigma_{\mathrm{g}}^{21}$ & $\sigma_{\mathrm{ge}}^{21}$ & $\sigma_{\mathrm{e}}^{21}$ & IL $^{1}$ & $h_{\mathrm{b}}^{21}$ & $S^{1}$ \\
\hline & & \multicolumn{6}{|c|}{ Botucatu and São Manuel (SP) 2010} \\
\hline Thousand grain weight (g) & 11.29 & 0.20 & 0.06 & 0.57 & 0.57 & 0.68 & 0.78 \\
\hline Grain yield (kg ha-1) & 31.63 & 20338 & 60087 & 344522 & -0.01 & 0.26 & 0.49 \\
\hline \multirow[t]{2}{*}{ Oil content (\%) } & 6.36 & 1.40 & 0.73 & 3.74 & 0.57 & 0.70 & 0.78 \\
\hline & & \multicolumn{6}{|c|}{ Botucatu and São Manuel (SP) 2011} \\
\hline Number of branches & 24.98 & 1.22 & 3.26 & 4.84 & 0.45 & 0.60 & 0.72 \\
\hline Grain yield $\left(\mathrm{kg} \mathrm{ha}^{-1}\right)$ & 35.82 & 16508 & 51128 & 79359 & 0.39 & 0.55 & 0.69 \\
\hline \multirow[t]{2}{*}{ Oil content (\%) } & 6.62 & 2.03 & 0.98 & 4.85 & 0.61 & 0.71 & 0.80 \\
\hline & & \multicolumn{6}{|c|}{ Botucatu (SP) 2010 and 2011} \\
\hline Thousand grain weight (g) & 10.90 & 0.15 & 0.10 & 0.58 & 0.45 & 0.61 & 0.73 \\
\hline Thousand grain weight (g) & 10.31 & 0.22 & 0.19 & 0.52 & 0.61 & 0.72 & 0.80 \\
\hline Number of branches & 18.72 & 1.84 & 2.53 & 4.66 & 0.59 & 0.70 & 0.79 \\
\hline Grain yield (kg ha $\left.{ }^{-1}\right)$ & 41.02 & 10007 & 30557 & 214730 & -0.08 & 0.22 & 0.46 \\
\hline Oil content (\%) & 4.95 & 1.38 & 1.6 & 2.62 & 0.67 & 0.76 & 0.83 \\
\hline
\end{tabular}

${ }^{1} \mathrm{CV}$ : experimental coefficient of variation; $\sigma_{\mathrm{ge}}^{2}$ : variance of genotype x environment interaction; $\sigma_{\mathrm{g}}^{2}$ : genetic variance among progenies; $\sigma_{\mathrm{e}}^{2}$ : environmental variance (error); IL: inferior limit heritability; $h_{b}^{2}$ :broad-sense heritability; SL: superior limit heritability. 
Genetic variation and gain in progenies of crambe

Table 5. Estimated genetic progress for grain yield with $10 \%$ intensity of selection in percentage of the mean of the progenies

\begin{tabular}{lccccc} 
& \multicolumn{2}{c}{ Genetic gain } & \multicolumn{2}{c}{ Genetic gain } \\
Season of selection & $(\%)$ & $\left(\mathrm{kg} \mathrm{ha}^{-1}\right)$ & Season of selection & $(\%)$ & $\left.(\mathrm{kg} \mathrm{ha})^{-1}\right)$ \\
\hline Botucatu 2010 & 22.1 & 432.8 & Two locations - 2010 & 124.0 & 8.3 \\
São Manuel 2010 & 9.3 & 163.1 & Two locations - 2011 & 21.4 & 168.3 \\
Botucatu 2011 & 36.8 & 391.1 & Two years - Botucatu & 15.9 & 251.2 \\
São Manuel 2011 & 48.9 & 249.3 & Two years - São Manuel & 6.6 & 82.0 \\
\hline
\end{tabular}

to improve the cultivar. The values ranged from 6.6 to $21.4 \%$ with gain selection obtained by the average joint of the experiments, resulting in increases in the grain yield from 74.7 to $240.2 \mathrm{~kg} \mathrm{ha}^{-1}$ (Table 5). Genetic gains expected based on averages of joint evaluations are the most reliable for the breeding, as it represents the most stable selection of progenies, i.e. the superior progenies in different locations or years, with expectations that they were superior due to the genetic characteristics instead of the environmental factors. Mastebroek et al. (1994) obtained $15 \%$ of genetic gain for grain yield with the selection of lines of crambe from Europe. Lessman (1975) obtained expected genetic gains of $1.13 \%$ for oil content, $14.11 \%$ for grain weight, and $6.69 \%$ for grain yield with the selection of individual plants. On common bean crop, Santos et al. (2002) observed genetic gains varying from 0.63 to $16.09 \%$ using the same selection method. It is important to emphasize that the genetic gains calculated in this study were based on the mean of progenies selected in the first step, which might be higher if they are based on the mean yield, which ranged from 563.4 to 1611.3 $\mathrm{kg} \mathrm{ha}^{-1}$ (Table 3).

The lack of variability in C. abyssinica reported by some authors (Lessman and Meyer 1972, Papathanasiou et al. 1966) was not observed in this study. Some studies have reported the importance of crossing between the species $C$. abyssinica and C. hispanica to increase genetic variability in crambe (Meier and Lessman 1973). The base population used in this study had sufficient genetic variability for selection. This can be attributed to the fact that the cultivar was obtained by mass selection and little improvement has been made since then. The cultivar has been subject to natural mutation and possible cross-pollination occurred over the years of growing crambe, and this may have contributed to the increase of genetic variability. This was also verified in common bean by Santos et al. (2002). The authors indicate that, even though most part of this variation is lost due to only a small sample of harvested grains is utilized as seeds, it is assumed that sufficient variation is remained for a successful selection.

In Brazil, soybean is the main raw material for oil production, responsible for more than $70 \%$ biofuel produced in the country. Therefore, new oilseeds that produce inedible oil have been sought for biofuel production within international quality standards (Silva 2008). Little-known crops in Brazil, such as crambe are atractive alternatives for biofuel production. Crambe is a winter crop, and due to this, interest has been aroused as an alternative for offseason or crop rotation However, the presence of only one genotype registered in Brazil for growing crambe hampers the crop growth in the country. Besides the grain yield below the productive potential of the species, genotypes have a specific adaptation to the location of selection. Hence, it is important that more productive materials are selected with breeding and meet the different growth conditions for the off-season in Brazil. It is important to consolidate the breeding programs of crambe in Brazil, as this crop can be inserted in different regions of Brazil due to the availability of superior genetic materials. It was concluded that there is genetic variability among selected crambe progenies and there was genetic gain for selection based on grain yield, demonstrating the efficiency of individual plant selection with progeny test method in crambe.

\section{REFERENCES}

Andrade ET, Correa PC, Teixeira LP, Pereira RG and Calomenij F (2006) Cinética de secagem e qualidade de sementes de feijão. Engevista 8: 83-95

Azevedo Filho JA, Vello NA and Gomes RLF (1998) Estimativas de parâmetros genéticos de populações de soja em solos contrastantes na saturação de alumínio. Bragantia 57: 227-239.

Cargnin A, Souza MA, Carneiro PCS and Sofiatti V (2006) Interação entre genótipos e ambientes e implicações em ganhos com seleção em trigo. Pesquisa Agropecuária Brasileira 41: 987-993.

Coelho ADF, Cardoso AA, Cruz CD, Araújo GAA, Furtado MR and Amaral CLF (2002) Herdabilidades e correlações da produção do feijão e dos seus componentes primários, nas épocas de cultivo da primaveraverão e do verão-outono. Ciência Rural 32: 211-216.

Coimbra JLM, Guidolin AF, Carvalho FIF, Coimbra SMM and Hemp S (1999) Reflexos da interação genótipo $x$ ambiente e suas implicações nos ganhos de seleção em genótipos de feijão (Phaseolus vulgaris L.). 
Ciência Rural 29: 433-439.

Cruz CD (2001) Programa genes: aplicativo computacional em genética e estatística. UFV, Viçosa, 442p.

Deitos A, Arnhold E and Miranda GV (2006) Yield and combining ability of maize cultivars under different ecogeographic conditions. Crop Breeding and Applied Biotechnology 6: 222-227.

FAO (1974) The legend of the soil map of the world. 1, UNESCO, Paris,

Falasca SL, Flores N, Lamas MC, Carballo SM and Anschau A (2010) Crambe abyssinica: An almost unknown crop with a promissory future to produce biodiesel in Argentina. Internacional Journal Hydrogen Energy 35: 5808-5812.

Fontana F, Lazzeri L, Malaguti L and Galletti S (1998) Agronomic characterization of some Crambe abyssinica genotypes in a locality of the Po Valley. European Journal of Agronomy 9: 117-126.

Hinman CW (1986) Potential new crops. Scientific American 255: 33-37.

Kaefer JE, Guimarães VF, Richart A, Tomm GO and Müller AL (2014) Produtividade de grãos e componentes de produção da canola de acordo com fontes e doses de nitrogênio. Pesquisa Agropecuária Brasileira 49: 273-280.

Knapp SJ, Stoup WW and Ross WM (1985) Exact confidence intervals for heritability on a progeny mean basis. Crop Science 25: 192-194.

Knights SE Crambe: a North Dakota case study. Rural Industries Research and Development Corporation, RIRDC Publication No W02/005, RIRDC Project No TA001-55. Available at <http://www.rirdc.gov.au/ reports/NPP/02-005.pdf>. Accessed in Jan, 2014.

Kruger CAMB, Silva JAG, Medeiros SLP, Dalmago GA, Sartori CO and Schiavo J (2011) Arranjo de plantas na expressão dos componentes da produtividade de grãos de canola. Pesquisa Agropecuária Brasileira 46: 1448-1453.

Lazzeri L, Mattei F, Bucelli F and Palmieri S (1997) Crambe oil: a potential new hydraulic oil and quenchant. Industrial Lubrification Tribology 49: 71-77.

Lessman KJ (1975) Variation in Crambe abyssinica Hocht. Journal American Oil Chemist's Society 52: 386-389.

Lessman KJ and Berry C (1967) Crambe and vernonia research results at the forage farm in 1966. Purdue University, Agricultural Experiment Station, West Lafayette, 3p. (Research Progress Report, 284)
Lessman KJ and Meyer JD (1972) Agronomic evaluation of crambe as a source of oil. Crop Science 12: 224-227.

Lynch M and Walsh B (1998) Genetics and Analysis of Quantitative Traits. Sunderland, Sinauer Associates, 980p.

Mastebroek HD, Wallenburg SC and Van Soest LJM (1994) Variation for agronomic characteristics in Crambe (Crambe abyssinica Hochst ex Fries). Industrial Crops and Products 2: 129-136.

Mauro AO, Costa LC and Perecin D (1999) Análises genéticas no desenvolvimento de variedades de soja para cultivo em áreas de reforma de canavial. Revista Ceres 46: 423-433.

Papathanasiou GA, Lessman KJ and Nyquist WE (1966) Evaluation of eleven introductions of crambe, Crambe abyssinica Hochst. Agronomy Journal 58: 587-589.

Pimentel-Gomes F (1985) Curso de estatística experimental. Editora Nobel, São Paulo, 467p.

Pitol C (2008) Cultura do crambe. In Tecnologia e produção: Milho safrinha e culturas de inverno. Fundação MS, Maracajú, p. 85-88.

Pitol C, Broch DL and Roscoe R (2010) Tecnologia e produção: crambe. Fundação MS, Maracajú, 60p.

Ramalho MAP, Pinto CABP and Santa Cecília FC (1982) Avaliação de amostra de cultivares de feijão roxo e seleção de progênies. Ciência e Prática 6: 35-43.

Santos PSJ, Abreu AFB and Ramalho MAP (2002) Seleção de linhas puras no feijão 'Carioca'. Ciência e Agrotecnologia Edição Especial: 1492-1498.

Souza ARR, Miranda GV, Pereira MG and Souza LV (2009) Predicting the genetic gain in the Brazilian white maize landrace. Ciência Rural 39: 19-24.

Silva PRF and Freitas TFS (2008) Biodiesel: the burden and the bonus of producing fuel. Ciência Rural 38: 843-851.

Vencovsky R (1978) Herança quantitativa. In Paterniani E (ed.) Melhoramento e produção de milho no Brasil. Fundação Cargill, Piracicaba, p. 122-201.

Vollmann J and Ruckenbauer P (1993) Agronomie performance and oil quality of crambe as affected by genotype and environment. Die Bodenkultur 44: 335-343. 